\title{
The impact of suburbanization on remnant coastal vegetation in Hobart, Tasmania
}

\author{
O'Shea, E.M. \& Kirkpatrick, J.B.* \\ School of Geography and Environmental Studies, University of Tasmania, Hobart, Box 252-78, GPO, Hobart, \\ Tasmania 7001, Australia; ${ }^{*}$ Corresponding author; Fax +61362262989; E-mail j.kirkpatrick@utas.edu.au
}

\begin{abstract}
Changes in vascular species composition and abundance were examined in coastal vegetation at Hobart, Tasmania, Australia over a period of $13 \mathrm{yr}$, during which suburbanization extended to cover a large proportion of its hinterland. There were significant increases in the richness and cover of exotic vascular plant species, most of which derived from the Mediterranean basin or southern Africa. While most of the introduced species were confined to vegetation with a high exotic component, and close to domestic gardens, some, including the South African coastal shrub, Chrysanthemoides monilifera, expanded in otherwise native vegetation relatively remote from gardens. The impact of proximity to gardens on the relative abundance of exotics and natives in coastal vegeta tion in 1997 best correlated with the pattern of distance from gardens in 1966, suggesting that there is, at least, a 30 -yr lag period in transformation from largely native to substantially exotic vegetation. This lag period provides an opportunity to reduce exotic invasion problems before they become severe.
\end{abstract}

Keywords: Australia; Chrysanthemoides monilifera; Exotic species; Garden; Introduced species; Vegetation change.

Nomenclature: Buchanan (1999) for native and naturalized species; Page \& Olds (1997) for garden plants.

\section{Introduction}

Remnants of native vegetation in built up areas are often important for biological conservation (e.g. Kirkpatrick 1994) and for passive recreational use. Yet, the maintenance of natural vegetation within, and adjacent to, built up areas in Australia and elsewhere is a difficult task, especially if the vegetation remnants are small with high perimeter/area ratios (Amor \& Piggin 1977; Clements 1983; Kirkpatrick 1986). Dry coastal vegetation is particularly susceptible to introduced species invasion, as it is downslope of development and experiences a relatively high level of natural, as well as humaninduced, disturbance. For example, rapid changes in the balance of native and introduced species, and in their relative abundances, were recorded with the suburbanization of the hinterland of the Sandringham coast in Melbourne, Victoria, Australia (Kirkpatrick 1974,
1975). This study appears to stand alone in documenting changes in the flora and vegetation in coastal environments as a result of suburbanization. Unfortunately, it was based on a rather coarse initial set of information, and could therefore give little indication of the rate of deterioration of the vegetation consequent upon suburbanization.

The coastal vegetation of the western shore of Hobart, Tasmania, Australia provided an opportunity to study the spatial and temporal nature of introduced species invasion and changes in abundance of native species over a period in which substantial expansion of suburbs took place. We were particularly interested in establishing the lag time (Scott \& Panetta 1993; Hobbs \& Humphries 1995) between suburbanization and exotic takeover, and in establishing the relative threats of different species. We use these data to discuss the implications of our results for conservation management of remnant native foreshore vegetation in Australian cities.

\section{Methods}

In $1984,655 \mathrm{~m} \times 5 \mathrm{~m}$ quadrats were randomly located in sections of the foreshore with uncultivated vegetation between Blinking Billy Point and Kingston in Hobart, Tasmania $\left(42^{\circ} 25^{\circ} \mathrm{S}, 146^{\circ} 53^{\prime} \mathrm{E}\right)$. Each quadrat was located parallel to the high tide mark, with its seaward side just including the vascular plants closest to the sea. These quadrats were resampled in 1997 , with the exception of one that had been converted into concrete. Additional samples were obtained in 1997 , making a total of 165 quadrats.

In each quadrat, all observed vascular plant taxa were recorded, with their abundances being indicated by the following cover scores: $1=<1 \% ; 2=1-5 \% ; 3=$ $5-25 \% ; 4=25-50 \% ; 5=50-75 \%, 6=75-100 \%$. The following data were recorded for each quadrat in 1997 : slope, using a clinometer; aspect, using a compass and placed into five classes ( $1=$ northwest; $2=$ north and west; $3=$ northeast and southwest; $4=$ south and east; 5 = southeast); geological type (sedimentary, igneous); bare ground cover, using the cover score scale; soil depth, 
which was the mean of the depths recorded from five vertical penetrations of a metal rod; height of tree layer; height of shrub layer; height of ground layer; total vegetation cover, cover of the tallest stratum and cover of the ground layer using the cover score scale. Aerial photographs taken in 1966,1977, 1985 and 1995 were used to measure the distance of each quadrat from the nearest house at each time.

The percentage of exotic taxa in each quadrat was calculated. The mid point of the range of each cover score was used to gain a total cover score for each quadrat. The percentage of this score attributable to exotic plants was then calculated. Correlation coefficients were calculated between each of these two variables and each of the distance from house variables for the total data set and subsets.

A sorted table of the quadrat species presence/absence data, with the two time periods for each site being treated as different samples, was produced using the polythetic, divisive procedure in TWINSPAN (Hill 1979). Five communities were selected from this table, which did not need any manual resorting of samples. The same data set was ordinated using global non-metric multidimensional scaling, following the default options in DECODA (Minchin 1991). This ordination technique has been demonstrated to be superior to those in the factor analysis family (Kenkel \& Orlóci 1986; Minchin 1987). Vectors of best fit in the ordination configuration were determined for all continuous and ordered multistate variables using the procedure in DECODA (Minchin 1991). The significance of the correlation of each vector with the ordination scores, was determined using the Monte Carlo technique in DECODA (Minchin 1991). The relationships between community, merging the $P o a$ poiformis community with the Pultenaea daphnoides community because of low numbers in the latter, and all continuous and ordered multistate variables were determined using one way analysis of variance. The relationships between community, again merging the two communities, and geological type was determined using the $\chi^{2}$-test. Means and standard errors were calculated to show the relationship between the proportionate abundance of exotics in quadrats and the occurrence of the more common introduced species.

The regression procedures in Minitab Inc. (Anon. 1998) were used for the sedimentary rock subset of the 1997 data. One analysis used the exotic cover/total cover as the dependent variable, while another used exotic richness/ total richness as the dependent variables. The independent variables included in both analyses were distance from houses in 1966, aspect code, slope and soil depth. A stepwise analysis was used, with the $F$-value for entry or removal set at 4 .

\section{Results}

\section{Native vegetation and recent disturbance patterns}

The coast in the study area largely consists of degraded cliffs and rocky shores, although some small cobble and sand beaches lie below the cliffs in places. While much of the native vegetation of the study area had been heavily invaded by exotics by 1984 , a sufficient native component remained to be able to roughly reconstruct the native vegetation communities and their zonation, which conform with general descriptions of well-drained, non-sandy low energy coastal areas in Tasmania (Kirkpatrick 1993; Kirkpatrick \& Harris 1995). There was a poorly-represented zone closest to the high tide mark in which the succulent herb, Sarcocornia quinqueflora, and a tussock grass, Austrostipa stipoides, were the most common species. Inland from this zone on rocky shores, the succulent scramblers, Tetragonia implexicoma and Rhagodia candolleana, were variably dominant, while the tussock grass, Poa poiformis, tended to dominate on soils. To the rear of this zone, there was scrub to low forest dominated by Allocasuarina verti. cillata, and with Dodonaea viscosa prominent. Occasional emergent eucalypts occurred within this zone, and eucalypts, largely Eucalyptus viminalis, E. globulus and E. tenuiramis, dominated to its rear.

Houses and gardens, where they occur adjacent to the coastal vegetation of the study area, directly juxtapose to it, with no road in between. The houses and gardens rarely extend to the lower slopes of the cliffs, leaving a narrow band of directly untransformed vegetation. There were no fires in any of the sampled vegetation between 1984 and 1997 and no signs of recent fires in any of it in 1984. Other disturbances during the period were highly localized. These included some dumping of garden waste material over cliffs, some localized incidences of water runoff from gardens, occasionally causing slumps, very localized falls of material from the steeper parts of cliffs and wave erosion at the bases of some cliffs.

\section{Introduced species}

Two thirds of the 76 introduced taxa recorded in quadrats were from Eurasia, North Africa and the north Atlantic islands (Table 1), most occurring naturally in the Mediterranean area. $18 \%$ of the exotic taxa were from South Africa, $7 \%$ from South America, and 4\% each were from North America and Australasia (Table 1). Almost all of the herbs and more than $50 \%$ of the graminoid species originated from Eurasia, North Africa and the north Atlantic islands (Table 1). South Africa contributed the largest number of succulent species (Table 1). In terms 
Table 1. Introduced species in the study area by life form and origin, showing the number of quadrats in which they occurred. In addition three species from Australasia occurred: Acacia retinodes (1 quadrat), Coprosma repens (2), Pittosporum undulatum (3).

\begin{tabular}{|c|c|c|c|c|}
\hline \multirow[t]{2}{*}{ Life form } & \multicolumn{4}{|c|}{ Origin } \\
\hline & $\begin{array}{l}\text { Eurasia, N. Africa } \\
\text { and N. Atlantic islands }\end{array}$ & South Africa & South America & North America \\
\hline Trees and shrubs & $\begin{array}{l}\text { Cotoneaster spp. } 5 \\
\text { Echium candicans } 5 \\
\text { Genista monspessulana } 3 \\
\text { Genista stenopetala } 2 \\
\text { Rosa rubiginosa } 7 \\
\text { Salix alba } 5 \\
\text { Ulex europaeus } 1\end{array}$ & $\begin{array}{l}\text { Chrysanthemoides monilifera } \\
\text { ssp. monilifera } 59 \\
\text { Lycium ferocissimum } 22 \\
\text { Pelargonium spec. } 14\end{array}$ & Fuchsia magellanica 1 & $\begin{array}{l}\text { Ceanothus impressus } 1 \\
\text { Ribes sanguineum } 1\end{array}$ \\
\hline Scrambiers/climbers & $\begin{array}{l}\text { Hedera helix } 4 \\
\text { Rubus fruticosus } 7 \\
\text { Vinca major } 4\end{array}$ & Delairea odorata 1 & $\begin{array}{l}\text { Passiflora mollissima } 8 \\
\text { Tropaeolum majus } 9\end{array}$ & \\
\hline Succulents & Aeoniun arboreum 32 & $\begin{array}{l}\text { Crassula spec. } 2 \\
\text { Drosanthemum floribundum } 2 \\
\text { Lampranthus spec. } 1\end{array}$ & Carpobrotus aequilateralis 1 & \\
\hline Graminoids & $\begin{array}{l}\text { Avena fatua } 1 \\
\text { Briza maxima } 8 \\
\text { Bromus diandrus } 1 \\
\text { Bromus hordeaceus } 13 \\
\text { Bromus sterilis } 23 \\
\text { Dactylis glomerata } 16 \\
\text { Holcus lanatus } 11 \\
\text { Lolinm perente' } 1\end{array}$ & $\begin{array}{l}\text { Agapanthus praecox } 3 \\
\text { Chlorophytum comosum } 1 \\
\text { Ehrharta erecta } 4 \\
\text { Kniphofia spec. } 1\end{array}$ & & \\
\hline Herbs & $\begin{array}{l}\text { Actmihus mollis } 1 \\
\text { Anagallis arvensis } 1 \\
\text { Calendula officinalis } 1 \\
\text { Cariamine depressa } 1 \\
\text { Cardaria draba } 1 \\
\text { Centranthus ruber } 4 \\
\text { Cerastium glomeratum } 1 \\
\text { Cirsium vulgare } 3 \\
\text { Erodium moschatum } 1 \\
\text { Foeniculum vulgare } 13 \\
\text { Fumaria spec. } 13 \\
\text { Galium aparine } 13 \\
\text { Helminthotheca echioides } 6 \\
\text { Hypochoeris radicata } 7 \\
\text { Lavatera arborea } 1 \\
\text { Lobularia maritima } 1 \\
\text { Malva sylvestris } 1 \\
\text { Petroselinum crispum } 4 \\
\text { Plantago coronopus } 1 \\
\text { Plantago lanceolata } 2 \\
\text { Polygomum aviculare } 1 \\
\text { Raphanus raphanistrum } 2 \\
\text { Rumex spp. } 2 \\
\text { Silene gallica } 6 \\
\text { Silybum marianum } 4 \\
\text { Sinapsis arvensis } 2 \\
\text { Sonchus asper } 12 \\
\text { Sonchus oleraceus } 18 \\
\text { Stellaria media } 1 \\
\text { Trifolium repens } 3 \\
\text { Veronica persica } 1 \\
\text { Vicia spp. i0 }\end{array}$ & $\begin{array}{l}\text { Arctotheca calendula } 1 \\
\text { Dimorphotheca phuvialis } 1 \\
\text { Gazania spec. } 5\end{array}$ & Conyza bonariensis 1 & Oxalis latifolia 8 \\
\hline
\end{tabular}




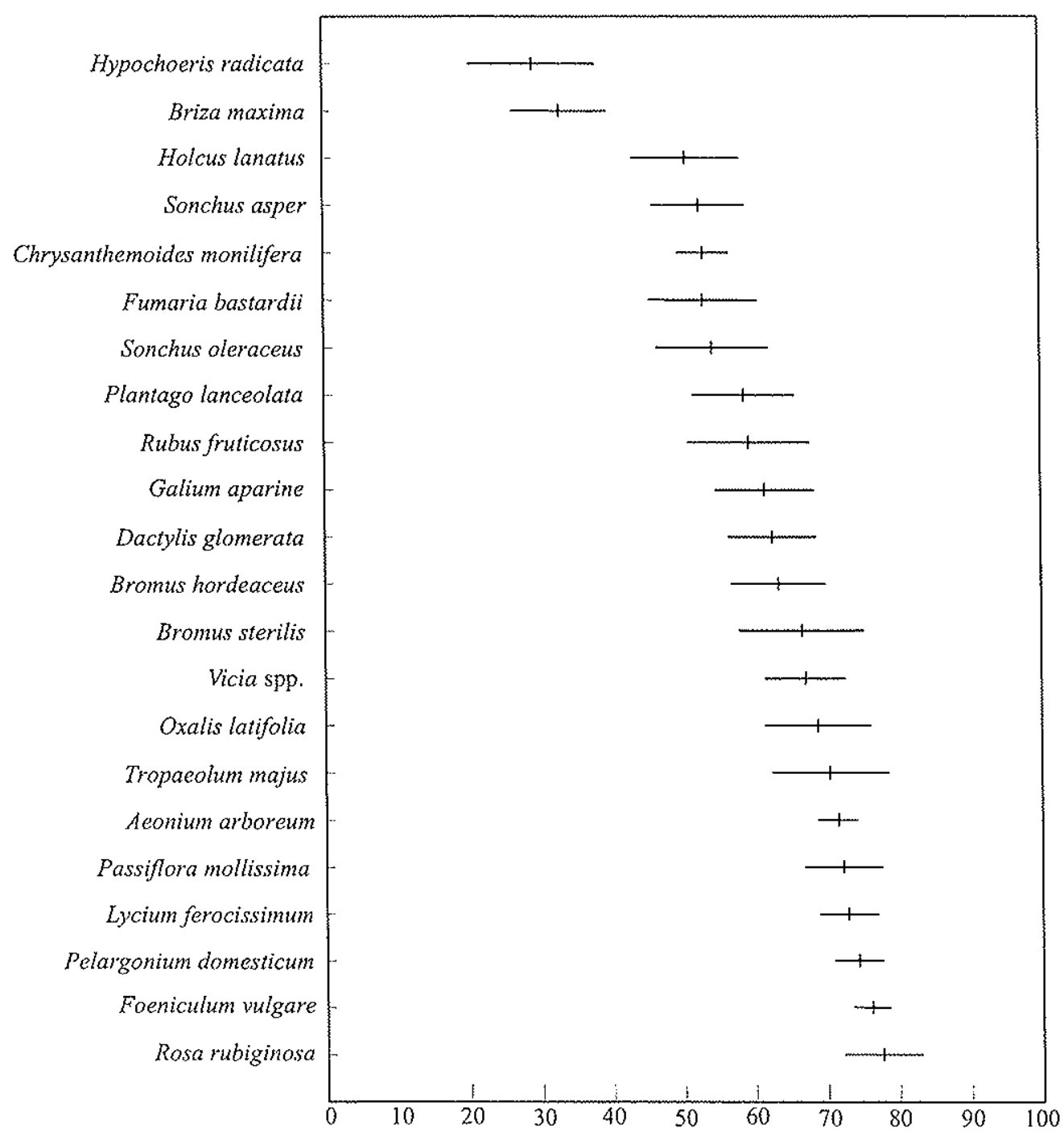

Fig. 1. Distribution of the 22 most common exotic taxa in relation to the proportion of cover attributable to introduced species. The horizontal lines represent the one standard error on either side of the mean, which is shown by a vertical line. If the lines do not overlap, the taxa have significantly different distributions at $P<0.05$.

of penetration of the vegetation, as indicated by frequency, South Africa dominated the shrubs, South America dominated the scramblers and climbers and Eurasia dominated the other life form classes (Table 1).

Of the 22 most common introduced species, only Briza maxima and Hypochoeris radicata were concentrated in quadrats in the lower range of exotic cover values (Fig. 1). Both are colonizers of bare ground and widespread in largely native vegetation. Chrysanthemoides monilifera was found in significantly more native vegetation on average than other non-herbaceous introduced species (Fig. 1).

\section{Classification and ordination of quadrats}

The communities, which are named by their most frequent native species, varied from largely exotic in species composition and cover to largely native, in the sequence from the Tetragonia implexicoma community to the Pultenaea daphnoides community (Table 2). In the Tetragonia implexicoma community the mean proportion of introduced species in quadrats was $77 \%$, while in the Pultenaea daphnoides community there were none (Table 2). Similarly, the mean proportion of cover attributable to introduced species varied between $70 \%$ in the Tetragonia implexicoma community to zero in the Pultenaea daphnoides community (Table 2). The communities varied in mean species richness, with the 
extremes being 10.3 in the Tetragonia implexicoma community and 6.8 in the Rhagodia candolleana community (Table 2).

In the two dimensional ordination (stress $=0.1456$ ) the Tetragonia implexicoma community formed one extreme and the Pultenaea daphnoides community the other. Variation between communities was largely continuous (Fig. 2). Several of the vegetation variables had significant $R$-values for their vectors in ordination space (Fig. 2), with the most significant vectors being introduced species richness/total species $(R=0.7464, P=$ $0.000)$ and exotic cover/total cover $(R=0.6338, P=$ $0.000)$.

The Tetragonia implexicoma and Rhagodia candolleana communities are largely located in the original zone dominated by succulent scramblers, the Allocasuarina verticillata and Poa poiformis communities

Table 2. Percentage frequency of taxa which occur in more than $25 \%$ of quadrats in at least one community by communities and mean values for vegetation variables. * = introduced species. The figures in bold indicate that the species attains its maximum percentage frequency in the community. The communities are named by their most frequent native species: $\mathrm{Ti}=$ Tetragonia implexicoma, $\mathrm{Rc}=$ Rhagodia candolleana, $\mathrm{Av}=$ Allocasuarina verticillata, $\mathrm{Pp}=$ Poa poiformis, $\mathrm{Pd}=$ Pultenae a daphnoides.

\begin{tabular}{|c|c|c|c|c|c|}
\hline \multirow[t]{2}{*}{ Taxon } & \multicolumn{5}{|c|}{ Community } \\
\hline & $\mathrm{Ti}$ & $\mathrm{Rc}$ & Av & $\mathrm{Pp}$ & $\mathrm{Pd}$ \\
\hline Tropaeolum majus* & 33 & 4 & - & - & - \\
\hline Pelargonium spec.* & 31 & 26 & - & - & - \\
\hline Lycium ferocissimum* & 41 & 34 & 15 & - & - \\
\hline Foeniculum vulgare* & 44 & 11 & 2 & - & - \\
\hline Fumaria bastardii* & 28 & 11 & 10 & 9 & - \\
\hline Tetragonia implexicoma & 85 & 53 & 47 & 51 & - \\
\hline Galium aparine* & 41 & 2 & 10 & 6 & - \\
\hline Bromus sterilis* & 36 & 23 & 27 & 9 & - \\
\hline Sonchus oleraceus* & 36 & 7 & 27 & 9 & - \\
\hline Aeonilm arborenm* & 54 & 57 & 15 & 3 & - \\
\hline Rhagodia candolleana & 23 & 66 & 2 & 14 & * \\
\hline Chrysanthemoides monilifera* & 59 & 77 & 70 & 40 & - \\
\hline Plantago lanceolata ${ }^{*}$ & 41 & 15 & 42 & 3 & - \\
\hline Dodonaea viscosa & 3 & 9 & 52 & 14 & - \\
\hline Allocasuarina verficillata & 10 & 9 & 60 & 40 & - \\
\hline Dactylis glomerata* & 15 & 13 & 40 & - & - \\
\hline Bromus hordeaceus* & 21 & - & 30 & 6 & 25 \\
\hline Notodanthonia spp. & 21 & 11 & 30 & 37 & - \\
\hline Poapoiformis & - & 9 & 57 & 69 & . \\
\hline Senecio linearifolius & - & 11 & 2 & 40 & - \\
\hline Lomandra longifolia & - & 2 & 5 & 54 & 50 \\
\hline Bursaria spinosa & 3 & - & 5 & 3 & 50 \\
\hline Eucalyptus tenuiramis & - & 2 & - & 6 & 75 \\
\hline Pultenaea daphnoides & - & - & - & 6 & 100 \\
\hline Dichelachne crinita & - & - & - & - & 50 \\
\hline Mean species richness & 10 & 7 & 10 & 8 & 8 \\
\hline Mean \% exotic taxa & 77 & 61 & 56 & 19 & 0 \\
\hline Mean \% exotic cover & 70 & 61 & 50 & 14 & 0 \\
\hline
\end{tabular}

are largely located in the original zone dominated by $A$. verticillata and the Pultenaea daphnoides community is largely located in the zone dominated by eucalypts.

\section{Environmental relationships}

Communities were significantly differentiated by geology (Table 3). The Tetragonia implexicoma and Rhagodia candolleana communities occurred more often than expected on igneous rocks, and the Allocasuarina verticillata, Poa poiformis and Pultenaea daphnoides communities occurred more often than expected on sedimentary rocks. There was a relatively weak differentiation between communities on soil depth (Table 3), with the Allocasuarina verticillata community having deeper soils than the rest. The vector for soil depth in the ordination configuration was not significant.

Aspect was significantly differentiated by community, with the Tetragonia implexicoma and Rhagodia condol. leana communities occurring preferentially on the more insolated aspects (Table 3). There was a significant vector for aspect in the ordination space (Fig. 2). However, there was no significant differentiation between communities on slope (Table 3), despite a significant vector in the ordination space (Fig. 2).

The pattern of distribution of igneous and sedimentary rocks partly coincides with the pattern of distribution of suburbia, with igneous rocks being more common on the long suburbanized coast and sedimentary rocks being more common on the more recently suburbanized, or unsuburbanized, coast. The same tendency prevails with soil depth. Less insolated aspects also tend to be more common in the more recently suburbanized areas. These environmental tendencies are not absolute, with a variety of rock types, aspects, and values for rock cover and soil depth being found in old suburban sites and those more recently suburbanized, or still far from suburbia.

Table 3. Community means for environmental variables. $\mathrm{Ti}=$ Tetragonia implexicoma, $\mathrm{Rc}=$ Rhagodia candolleana, $\mathrm{Av}=$ Allocasuarina verticillata, $\mathrm{Pp}=$ Poa poiformis, $\mathrm{Pd}=$ Pultenaea daphnoides, $(\mathrm{A})=\mathrm{ANOVA},(\mathrm{C})=$ chi square.

\begin{tabular}{|c|c|c|c|c|c|}
\hline \multirow[t]{2}{*}{ Variable } & \multicolumn{3}{|c|}{ Community } & \multirow[b]{2}{*}{$\mathrm{Pp}+\mathrm{Pd}$} & \multirow[t]{2}{*}{$P$} \\
\hline & $\mathrm{Ti}$ & $\mathrm{Rc}$ & Av & & \\
\hline \% Sedimentary & 27 & 42 & 87 & 100 & $0.000(\mathrm{C})$ \\
\hline Aspect ${ }^{*}$ & 3.6 & 3.6 & 4.1 & 4.0 & $0.012(\mathrm{~A})$ \\
\hline Soil depth (cm) & 12.8 & 10.8 & 13.9 & 8.5 & $0.048(\mathrm{~A})$ \\
\hline Slope $\left({ }^{\circ}\right)$ & 39 & 50 & 42 & 45 & $0.067(\mathrm{~A})$ \\
\hline
\end{tabular}


Vegetation change 1984 - 1997

The Iransition matrix (Table 4) shows that 1997 samples tended to fall into more exotic-rich classificatory communities than the 1984 samples from the same sites. Significantly more introduced species than native species increased their cover at sites between 1984 and $1997\left(\chi^{2}=4.54, \mathrm{~d} f=1, P<0.05\right)$. The same relationship prevailed for shrub species $\left(\chi^{2}=5.44\right.$, d.f. $\left.=1, P<0.05\right)$.

The non-annual and non-geophytic exotic plants that occurred in more than $5 \%$ of the quadrats in either or both years and increased their percentage frequency by more than $25 \%$ between 1984 and 1997 were the shrubs, Cotoneaster spp., Echium candicans and Genista spp., the climbers/scramblers, Passiflora mollissima, Tropaeolum majus and Rubus fruticosus, and the herbs, Centranthus ruber, Oxalis latifolia, Helminthotheca echioides and Hypochoeris radicata (Table 5). The first five of these
Table 4. Community transition matrix. The top left hand cell tells us that nine quadrat pairs sampled from the same places were in the Tetragonia implexicoma community in both in 1984 and 1997. The cell to the right tells us that nine quadrats sampled in the same places were in the Rhagodia candolleana community in 1984 and the Tetragonia implexicoma community in 1997. $\mathrm{T} \dot{\mathrm{i}}=$ Tetragonia implexicoma community, $\mathrm{Rc}=$ Rhagodia candolleana community, $\mathrm{Av}=$ Allocasuarina verticillata community, $\mathrm{Pp}=$ Poa poiformis community, $\mathrm{Pd}=$ Pultenaea daphnoides community.

\begin{tabular}{lrrrrr}
\hline Floristic & & \multicolumn{5}{c}{ Floristic community 1984} \\
community 1997 & Ti & Rc & Av & Pp & Pd \\
\hline $\mathrm{Ti}$ & 9 & 9 & 2 & 3 & 0 \\
$\mathrm{Rc}$ & 2 & 11 & 2 & 2 & 0 \\
$\mathrm{Av}$ & 0 & 3 & 8 & 3 & 0 \\
$\mathrm{Pp}$ & 0 & 0 & 4 & 3 & 1 \\
$\mathrm{Pd}$ & 0 & 0 & 0 & 0 & 0 \\
\hline
\end{tabular}
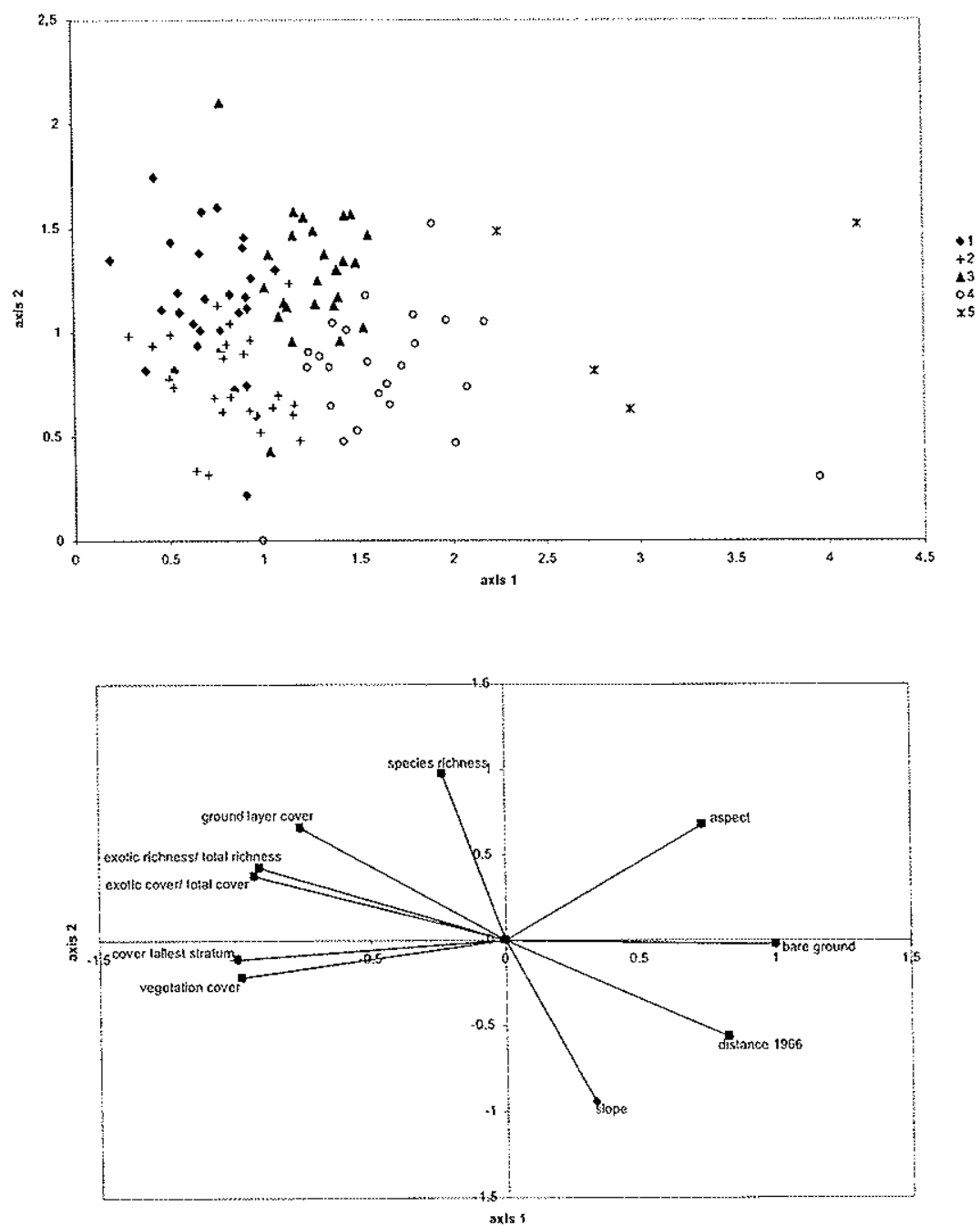

Fig. 2. Distribution of communities in two dimensional ordination space and significant vectors for vegetation and environmental variables. $1=$ Tetragonia implexicoma community, $2=$ Rhagodia candolleana community, $3=$ Allocasuarina verticillata community, $4=$ Poa poiformis community, $5=$ Pultenaea daphnoides community. 
Table 5. Percentage frequency and mean cover scores for taxa in quadrats sampled both in 1984 and 1997. These taxa occurred in at least $5 \%$ of quadrats in at least one year. Annuals and geophytes are excluded from the table. $\mathrm{C}=1997 / 1984 . *=$ introduced species.

\begin{tabular}{|c|c|c|c|c|c|c|}
\hline \multirow[t]{2}{*}{ Taxon } & \multicolumn{3}{|c|}{ \% frequency } & \multicolumn{3}{|c|}{ Mean cover score } \\
\hline & 1984 & 1997 & $\mathrm{C}$ & 1984 & 1997 & $\mathrm{C}$ \\
\hline \multicolumn{7}{|l|}{ Trees and shrubs } \\
\hline Echium candicans* & 1.6 & 12.5 & 7.81 & 0.03 & 0.34 & 11.33 \\
\hline Cotoneaster spp.* & 1.7 & 9.4 & 5.53 & 0.03 & 0.22 & 7.33 \\
\hline Genista spp.* & 1.6 & 7.8 & 4.87 & 0.03 & 0.23 & 7.67 \\
\hline Dodonaea viscosa & 9.4 & 20.3 & 2.16 & 0.19 & 0.59 & 3.11 \\
\hline Lycium ferocissintum* & 26.6 & 29.7 & 1.12 & 0.58 & 0.91 & 1.57 \\
\hline Pelargonium spec.* & 15.6 & 17.2 & 1.10 & 0.33 & 0.53 & 1.61 \\
\hline Chrysanthemoides monilifera* & 62.5 & 67.2 & 1.08 & 1.62 & 2.25 & 1.39 \\
\hline Allocasuarina verficillata & 26.6 & 28.1 & 1.06 & 0.58 & 0.80 & 1.34 \\
\hline Aeonitum arboreum* & 37.5 & 39.1 & 1.04 & 1.45 & 1.40 & 0.97 \\
\hline Rosa rubiginosa* & 9.4 & 4.7 & 0.50 & 0.14 & 0.14 & 1.00 \\
\hline \multicolumn{7}{|l|}{ Climbers and scramblers } \\
\hline Einardia nutans & 1.6 & 9.4 & 5.87 & 0.02 & 0.30 & 15.00 \\
\hline Rubus fruticosus* & 1.6 & 9.4 & 5.87 & 0.03 & 0.27 & 9.00 \\
\hline Passiflora mollissima* & 6.2 & 12.5 & 2.02 & 0.12 & 0.34 & 2.83 \\
\hline Rhagodia candolleana & 25.0 & 39.1 & 1.56 & 0.77 & 1.33 & 1.73 \\
\hline Tropaeolum majus* & 9.4 & 14.1 & 1.50 & 0.25 & 0.47 & 1.88 \\
\hline Tetragonia implexicoma & 54.7 & 67.2 & 1.23 & 1.58 & 2.09 & 1.32 \\
\hline \multicolumn{7}{|l|}{ Other herbs } \\
\hline Centranthus ruber* & 0.0 & 10.9 & & 0.00 & 0.27 & \\
\hline Oxalis latifolia* & 3.1 & 10.9 & 3.52 & 0.05 & 0.19 & 3.80 \\
\hline Helminthotheca echioides* & 4.7 & 9.4 & 2.00 & 0.05 & 0.20 & 4.00 \\
\hline Senecio spp. & 18.7 & 25.0 & 1.34 & 0.37 & 0.74 & 2.00 \\
\hline Hypochoeris radicata* & 6.2 & 7.8 & 1.26 & 0.08 & 0.12 & 1.50 \\
\hline Foeniculum vulgare* & 17.2 & 18.7 & 1.09 & 0.33 & 0.42 & 1.27 \\
\hline Bracteantha bracteata & 11.7 & 10.9 & 0.93 & 0.11 & 0.20 & 1.82 \\
\hline Plantago lanceolata* & 29.7 & 18.7 & 0.63 & 0.52 & 0.44 & 0.85 \\
\hline Gazania spec.* & 9.6 & 1.6 & 0.17 & 0.12 & 0.05 & 0.42 \\
\hline \multicolumn{7}{|l|}{ Monocotyledonae } \\
\hline Lomandra longifolia & 9.4 & 14.1 & 1.50 & 0.16 & 0.37 & 2.31 \\
\hline Dactylis glomerata* & 12.5 & 15.6 & 1.25 & 0.28 & 0.34 & 1.21 \\
\hline Poapoiformis & 25.0 & 25.0 & 1.00 & 0.55 & 0.69 & 1.25 \\
\hline Notodtmthonia spp. & 34.4 & 15.6 & 0.45 & 0.59 & 0.34 & 0.58 \\
\hline Austrostipa spp. & 10.9 & 4.7 & 0.43 & 0.19 & 0.14 & 0.74 \\
\hline
\end{tabular}

taxa are widely planted in gardens. The remainder are weeds of waste places and gardens. Other increasers among the exotics were the shrubs, Pelargonium spec., Aeonium arboreum, Chrysanthemoides monilifera and Lycium ferocissinum, the herb, Foeniculum vulgare, and the grass Dactylis glomerata (Table 5). The first three of these species are widely cultivated in gardens. The exotic decreasers were the shrub, Rosa rubiginosa, and the herbs, Plantago lanceolata and Gazania spp.

The non-annual and non-geophytic native plants that occurred in more than $5 \%$ of the quadrats in either or both years and increased their percentage frequency by more than $25 \%$ between 1984 and 1997 were the small tree Dodonaea viscosa, the scramblers Einardia nutans and Rhagodia candolleana, the tall herb Senecio spp. and the tussock graminoid Lomandra longifolia (Table 5). The other native increasers were the tree Allocasuarina verticillata, and the scrambler Tetragonia implexicoma (Table 5). The native species that decreased over the time period were the tall herb Bracteantha bracteata, and the grasses Notodanthonia spp. and Austrostipa spp. (Table 5).

Most of the species that demonstrated the greatest rates of increase in both frequency and cover scores over the time period were vigorous exotic shrubs and scramblers that have the potential to form a closed canopy that could exclude most of the smaller native species, in combination with the already well-established exotic shrubs, Chrysanthemoides monilifera, Lycium ferocissimum and Aeonium arboreum (Table 
Table 6. Product moment correlation coefficients for the relationships between distance from houses for different dates and: the percentage of exotic taxa in all 1997 quadrats (\%EA); the percentage of cover attributable to exotics for all 1997 quadrats (\%CA); the percentage of exotic taxa in 1997 quadrats on sedimentary rocks (\%ES); the percentage of cover atributable to exotics for 1997 quadrats on sedimentary rocks (\%CS); the percentage of exotic taxa in 1997 quadrats on south, east and southeast-facing slopes (\%EW); the percentage of cover attributable to exotics for 1997 quadrats on south, east and southeast-facing slopes (\%CW). All relationships are significant at $P<0.001$.

\begin{tabular}{lllllll}
\hline Date & $\% \mathrm{EA}$ & $\% \mathrm{CA}$ & $\% \mathrm{ES}$ & $\% \mathrm{CS}$ & $\% \mathrm{EW}$ \\
\hline 1966 & -0.620 & -0.548 & -0.624 & -0.617 & -0.704 & -0.657 \\
1977 & -0.533 & -0.477 & -0.578 & -0.559 & -0.642 & -0.609 \\
1986 & -0.507 & -0.446 & -0.540 & -0.528 & -0.566 \\
1995 & -0.510 & -0.451 & -0.543 & -0.531 & -0.608 & \\
\hline
\end{tabular}

2). C. monilifera is already the equally most frequent species in the study area and has the highest mean cover score. Its potential for increase does not appear to be exhausted.

Of the native species, only Dodonaea viscosa, a shade-tolerant small tree, and Einardia nutans, a drought tolerant, succulent scrambler and climber, more than doubled their percentage frequencies in the time period (Table 5). In the former case part of the increase can be attributed to the extension of canopies of trees present in 1984, although some seedling establishment was noted. The increase in frequency and cover of Einardia nutans may relate to the generally droughty conditions that have prevailed in Hobart during the 1990s.

\section{The impact of suburbanization}

The 1966 distances from houses (range $=16-462 \mathrm{~m}$, mean $=109 \mathrm{~m}$, median $=63 \mathrm{~m}$ ) provided the strongest relationship with both introduced species/total species and exotic cover/total cover (Table 6). The subset of quadrats on sedimentary rocks, which, unlike igneous rocks, were found throughout a range of distances from housing, showed the same pattern, as did the quadrats on south, east and southeast facing coasts (Table 6), suggesting that the influence of suburbanization on the proportion and relative abundance of exotics was not an artefact of the distribution of rock types or aspects.

Further confirmation of the overwhelming importance of distance from housing was gained from the regression analyses using quadrats on sedimentary rocks. For exotic cover/total cover in the stepwise analysis, distance from housing in 1966 accounted for $35.3 \%$ of the variance. The addition of aspect increased the explanation level to $57.9 \%$, and the further addition of soil depth increased it to $65.7 \%$. The regression equation $(F=15.96, P=0.000)$ is:

$Q_{\text {exot/tot }}=54.8+0.795 d+48.9 a-1.55 s d$ where $Q_{\text {exol/ot }}=$ the ratio exotic cover/total cover; $d=$ distance from houses in 1966, $a=$ aspect code and $s d=$ soil depth. For the ratio exotic richness/total richness in the stepwise analysis, distance from housing in 1966 accounted for $85.5 \%$ of the variance, and the addition of aspect increased this figure to $91.3 \%$. Here the regression equation $(\mathrm{F}=132.81, P=0.000)$ is:

$Q_{\text {exottot }}=17.3+0.837 d+17.6 a$

\section{Discussion}

It seems that there is at least a $30-y$ r lag period between suburbanization and the realization of its impacts on exotic richness and cover in adjacent remnant coastal vegetation, given that the highest correlations with the 1997 patterns for exotic cover/total cover and exolic richness/total richness are with the 1966 distances from houses. The relative results of the regression analyses on the sedimentary subset, with 1966 distances explaining a much higher proportion of the variance in exotic richness/total richness than in exolic cover/total cover, indicate that introduced species richness responds more rapidly to suburbanization than introduced species cover. This difference reflects the time required for the transition from local naturadization, to more extensive invasion to transformation, following the terminology of Richardson et al. (2000),

The ability of introduced species to displace native species in the particular context of the Hobart coast cannot be attributed to human impacts, either directly on vegetation or on the enviromment in which the vegetation grows, which are, and have been, relatively rare on the sampled parts of the degraded cliffs. These cliffs support a native flora well-adapted to the many 
natural disturbances, such as sodium chloride deposition and wave erosion, that occur in this environment. Suburbanization has decreased the incidence of one previously common disturbance, fire, that may have prevented the growth in cover of many of the exotics. For example, Cotoneaster spp. and Pittosporum undu. latum are relatively easily killed by fire (Gleadow \& Ashton 1981; Zacharek 1990). The most invasive of the species in the study area, Chrysanthemoides monilifera, does not require disturbance for establishment (Kirkpatrick 1986) and regenerates prolifically after fire, producing new seed within two years. Changes in disturbance regimes are unlikely to have caused its widespread dominance. The most reasonable hypothesis for the success of exotics is their advantage over native species in having left their predators and parasites in their homeland.

Some proportion of the increases in the cover and richness of introduced species that occurred in the study area between 1984 and 1997 may have occurred without any extension of the Hobart suburbs, simply as a result of the interaction of time with the dispersal ranges of individual introduced species. There are several welldocumented cases of similar increases occurring on islands relatively remote from urban areas (e.g. Norman et al. 1980; Schoenherr et al. 1999; Abbott et al. 2000). However, the strong influence of proximity to housing on exotic richness and cover in Hobart suggests that suburbanization had an overwhelming influence, in the same way as at Sandringham in Victoria, where largely native vegetation with few exotics was replaced by a synthetic vegetation with many exotics in the space of two decades, during which suburbanization of the hinterland was complete (Kirkpatrick 1974, 1975).

While many of the introduced species associated with close proximity of housing seem unlikely to become major threats to the integrity of native vegetation (e.g. Petroselinum crispum), others may be more threatening. Among the latter, Aeonium arboreum and Echium candicans may only be limited in their impact on coastal vegetation by lack of effective medium to long distance dispersal mechanisms, as they constitute a large part of the cover where houses have been longest. Bird-dispersed introduced species, such as Chrysanthemoides monilifera and Cotoneaster spp. are already widespread throughout the study area. Both are potential transformers, like Aeonium arboreum and Echium candicans.

The nature of the vegetation that will result from an unhindered continuation of the exotic invasion process can be at least partially deduced from the state of the most heavily invaded quadrats in the oldest suburban areas. The most salt and drought tolerant of the native species persist among exotics on unstable ground and close to the sea, with the remainder of the vegetation being a closed heath to closed scrub dominated by Echium candicans, Aeonium arboreum and Chrysanthe. moides monilifera with an occasional emergent Allocasuarina verticillata and Dodonaea viscosa. The key to further vegetation development may lie in the regeneration capabilities of $A$. verticillata and Dodonaea viscosa in a sea of exotic shrubs and the likely prolonged absence of fire. If $A$. verticillata can establish new individuals in sufficient density to establish a closed canopy, it may have the potential to eliminate much of the exotic cover (Kirkpatrick 1986). Dodonaea viscosa can form a closed canopy, but its litter does not suppress understorey growth to the same degree as that of $A$. verticillata.

An alternative scenario is the gradual loss of the native tree layer with inadequate regeneration to replace senescing individuals. Few young individuals of A. verticillata can be found among the exotic heaths and scrubs, although $D$. viscosa has been more successful. Thus, this latter scenario seems the most likely.

Our results suggest that, if no action is taken, the fate of remnani native coastal vegetation next to housing will be a transformation into vegetation largely dominated by exotics. This transformation may be in small part the result of environmental modification through accessions of nutrients and water from the domestic gardens that lie upslope. However, in the few areas where gardens are still remote from the coast, and could have little or no direct effect on environmental conditions, there are populations of many of the exotic plants that dominate the largely exotic vegetation adjacent to long gardened areas, most notably, of Chrysanthemoides monilifera. This and other exotic taxa, such as Cotoneaster spp. and Pittosporum undulatum, are dispersed by birds, some of which are native and others, such as Turdus merula, the European blackbird, introduced. Zacharek (1990) demonstrated that Cotoneaster seeds have a maximum dispersal range of $400 \mathrm{~m}$, a distance that excludes no part of the study area from invasion within two generations of this and other species with bird-dispersed seeds. The bird-dispersed shrubs are the exotic invaders that are most successful in displacing natives. They need to be eliminated not only from the coastal remnants, but also from their sources in gardens. There are at least two examples in Australian cities where persistent weeding by volunteers and council staff has almost eliminated bird-dispersed exotic shrub species. At least one small bush remnant on the Sydney Harbour shore is now almost free of such species (J.B. Kirkpatrick pers. obs.), and Chrysanthemoides monilifera has been almost eliminated from the Sandringham Coastal Reserve in Melbourne, where it was once one of the most 
common species (Kirkpatrick 1975).

Our results suggest that those wishing to manage coastal remnants to maintain naturalness might have the least difficulty in doing so by commencing their efforts in the early stages of invasion, before exotics begin to displace the natives (c.f. Hobbs \& Humphries 1995). There is a substantial lag time between suburbanization and such displacement that can be utilized.

\section{References}

Anon. 1998. Minitab release 12. Minitab Inc., State College, PA.

Abbott, I., Marchant, N. \& Cranfield, R. 2000. Long-term changes in the floristic composition and vegetation structure of Carnac Island, Western Australia. J. Biogeogr. 27: 333-346.

Amor, R.L. \& Piggin, L.M. 1977. Factors influencing the establishment and success of exotic plants in Australia. Proc. Ecol. Soc. Aust. 10: 15-26.

Buchanan, A.M. 1999. A census of the vascular plants of Tasmania. Tasmanian Herbarium Occasional Publication No. 6, Hobart.

Clements, A. 1983. Suburban development and resultant changes in the vegetation of the bushland of the northern Sydney region. Aust. J. Ecol. 8: 307-319.

Gleadow, R.M. \& Ashton, D.H. 1981. Invasion by Pittosporum undulatum of the forest of central Victoria. I. Invasion patterns and plant morphology. Aust. J. Bot. 29: 705-720.

Hill, M.O. 1979. TWINSPAN - a FORTRAN program for arranging multivariate data in an ordered two way table by classification of individuals and attributes. Cornell University, New York, NY.

Hobbs, R.J. \& Humphries, S.E. 1995. An integrated approach to the ecology and management of plant invasions. Conserv. Biol. 9: 761-770.

Kenkel, N.C. \& Orloci, L. 1986. Applying metric and nonmetric multidimensional scaling to ecological studies: some new results. Ecology 67: 919-928.
Kirkpatrick, J.B. 1974. Plant invasion and extinction in a suburban coastal reserve. Aust. Geogr. Stud. 12: 107-118.

Kirkpatrick, J.B. 1975. Vegetation change in a suburban coastal reserve. Aust. Geogr. Stud. 13: 137-153.

Kirkpatrick, J.B. 1986. The viability of bush in cities - ten years of change in an urban grassy woodland. Aust. J. Bot. 35: 691-708.

Kirkpatrick, J.B. 1993. Dry coastal ecosystems of southeastern Australia. In: van der Maarel, E. (ed.) Ecosystems of the World 2B: dry coastal ecosystems - Africa, America, Asia and Oceania, pp. 273-288. Elsevier, Amsterdam.

Kirkpatrick, J.B. 1994. A continent transformed - human impact on the natural vegetation of Australia. Oxford University Press, Sydney.

Kirkpatrick, J.B. \& Harris, S. 1995. The conservation of Tasmanian dry coastal vascular plant communities. Parks and Wildlife Service, Tasmania, Wildlife Scientific Report 95/1.

Minchin, P.R. 1987. An evaluation of the relative robustness of techniques for ecological ordination. Vegetatio 69: 89. 107.

Minchin, P.R. 1991. DECODA user's manual. Research School of Pacific Studies, ANU, Canberra.

Norman, F.I., Harris, M.P., Corrick, A.H. \& Carr, G.W. 1980. The flora and avifauna of Lady Julia Percy Island, Victoria, Australia. Proc. R. Soc. Vict. 91: 135-154.

Page, S. \& Olds, M. (eds.) 1997. Botanica. Random House, Milsons Point, NSW.

Richardson, D.M., Pyšek, P., Rejmánek, M., Barbour, M.G., Panetta, F.D. \& West, C.J. 2000. Naturalization and invasion of alien plants: concepts and definitions. Diversity Distributions 6: 93-107.

Schoenherr, A.A., Feldmeth, C.R. \& Emerson, M.J. 1999. Natural history of the islands of California. University of California Press, Berkeley, CA.

Scott, J.K. \& Panetta, F.D. 1993. Predicting the Australian weed status of South African plants. J. Biogeogr. 20:87. 93.

Zacharek, A. 1990. Bush invasion by Cotoneaster spp. in Hobart. Grad. Dipl. Env. Stud. (Hons.) Thesis, University of Tasmania, Hobart.

Received 2 August 1999; Revision received 10 October 2000 ; Accepted I November 2000. Coordinating Editor: J.P. Bakker. 